
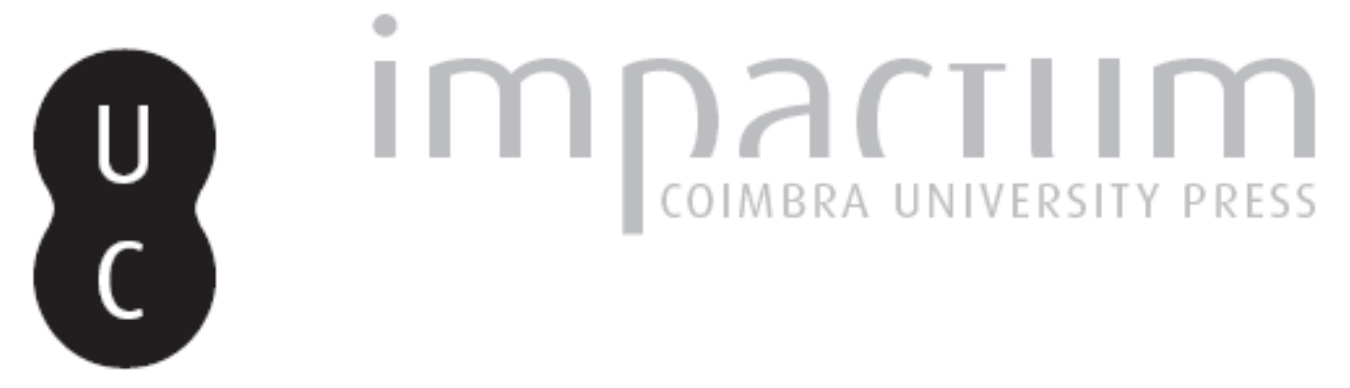

\title{
Prometeu: a sabedoria pelo trabalho e pela dor
}

\section{Autor(es): $\quad$ Azambuja, Celso Candido}

Publicado por: Annablume Clássica

URL persistente:

URI:http://hdl.handle.net/10316.2/24318

DOI:

DOI:http://dx.doi.org/10.14195/1984-249X_10_2

Accessed : $\quad$ 26-Apr-2023 11:27:00

A navegação consulta e descarregamento dos títulos inseridos nas Bibliotecas Digitais UC Digitalis, UC Pombalina e UC Impactum, pressupõem a aceitação plena e sem reservas dos Termos e Condições de Uso destas Bibliotecas Digitais, disponíveis em https://digitalis.uc.pt/pt-pt/termos.

Conforme exposto nos referidos Termos e Condições de Uso, o descarregamento de títulos de acesso restrito requer uma licença válida de autorização devendo o utilizador aceder ao(s) documento(s) a partir de um endereço de IP da instituição detentora da supramencionada licença.

Ao utilizador é apenas permitido o descarregamento para uso pessoal, pelo que o emprego do(s) título(s) descarregado(s) para outro fim, designadamente comercial, carece de autorização do respetivo autor ou editor da obra.

Na medida em que todas as obras da UC Digitalis se encontram protegidas pelo Código do Direito de Autor e Direitos Conexos e demais legislação aplicável, toda a cópia, parcial ou total, deste documento, nos casos em que é legalmente admitida, deverá conter ou fazer-se acompanhar por este aviso.

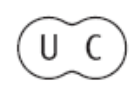



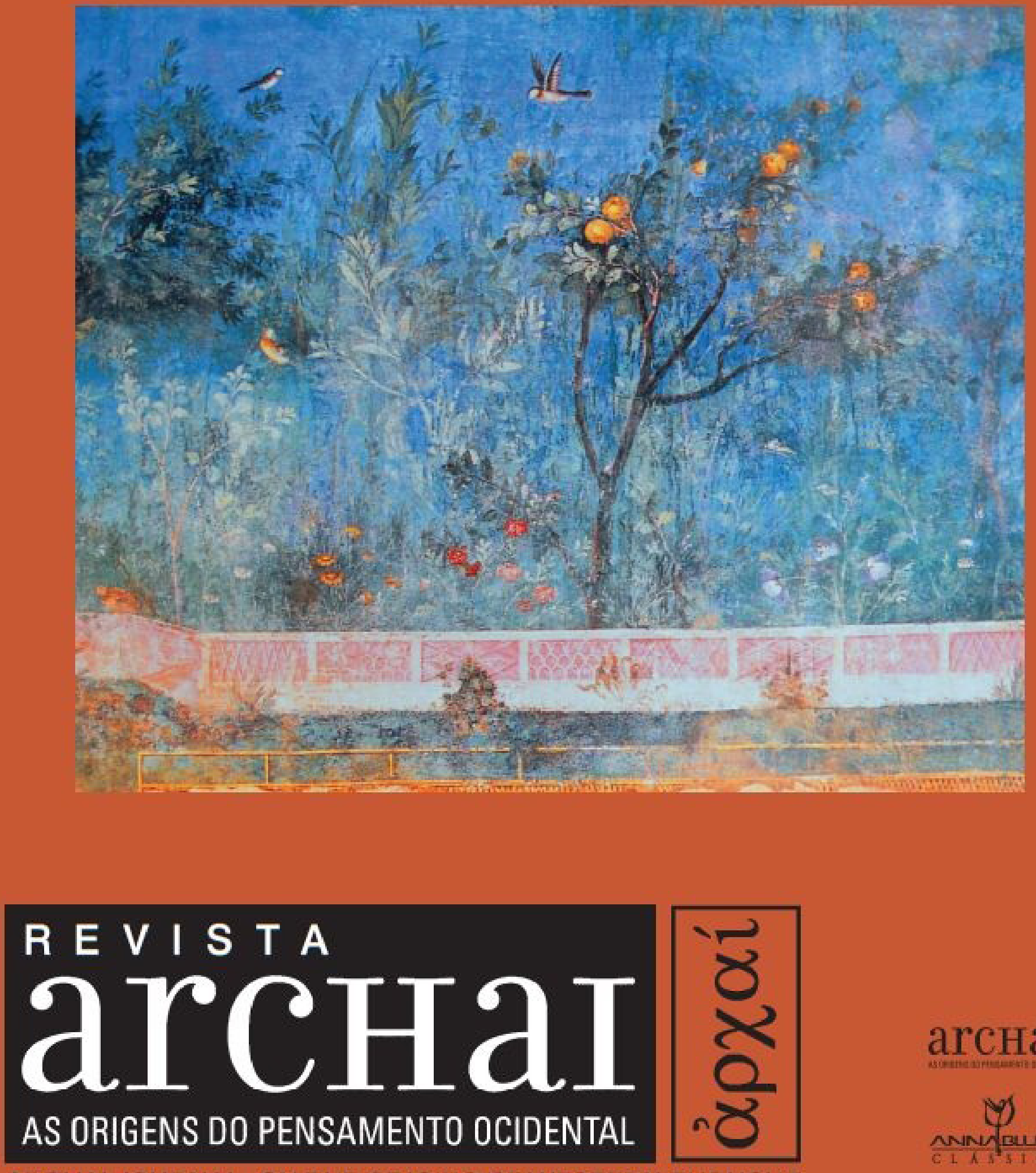

arcнаI

ARCHAI JOURNAL: ON THE ORIGINS OF WESTERN THOUGHT

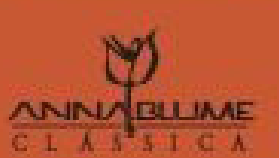




\section{PROMETEU: A SABEDORIA PELO TRABALHO E PELA DOR}

AZAMBUJA, C. C. (2013). Prometeu: a sabedoria pelo trabalho e pela dor. Archai, n. 10, jan-jul, p. 19-28.

RESUMO: Exploramos aqui as conexões do mito de Prometeu com o nascimento do iluminismo ocidental. 0 estudo tem como base as obras de Hesiodo e Ésquilo, a partir das interpretações de Werner Jaeger e Junito Brandão. Nos poemas de Hesíodo, Prometeu é aquele titã que roubou o fogo de Zeus para entregá-lo à humanidade. Por este gesto, Prometeu e seus protegidos são duramente castigados por Zeus. Assim, mergulhados em um mundo de incontáveis e incontornáveis males, os homens, honestos, conquistam a esperança de uma boa vida através do trabalho infatigável. Na tragédia de Ésquilo, Prometeu é apresentado como o iluminador e protetor da humanidade. Multi-sábio foi ele quem deu pensamento aos homens, pois estes faziam tudo sem razão. Todas as técnicas e artes humanas são devidas a Prometeu, o previdente. Aqui o mito revela o fundo a partir do qual brota a sabedoria humana: o sofrimento e a dor. No mito, revela-se, de modo essencial, a exigência do trabalho e a presença do sofrimento como condições de uma existência humana definida e considerada do ponto de vista do iluminismo. A sabedoria é a força capaz de fazer o homem superar os obstáculos e as adversidades. Prometeu representa, dessa forma, uma imagem primordial da condição humana cuja sabedoria é conquistada pelo trabalho e pela dor.

PALAVRAS-CHAVE: Prometeu, Sabedoria, Trabalho, Dor

ABSTRACT: We explore the connections of the myth of Prometheus with the Western Enlightenment and the human condition. The study is based on the works of Hesiod and Aeschylus, from
* Professor e pesquisador do Programa de Pós-Graduação em Filosofia da Universidade do Vale do Rio dos Sinos (UNISINOS).

Gostaria de agradecer a solícita e cuidadosa leitura, as excelentes críticas e sugestões generosamente feitas pelo colega Prof.

Dr. Luiz Rohden à primeira versão deste trabalho.

1. Segundo JUNG (1995), os arquétipos constituem parte importante do tecido subjetivo humano; eles são construções do "inconsciente coletivo"; de acordo com Jung, os "maiores e melhores pensamentos da humanidade são moldados sobre imagens primordiais". Estas imagens primordiais estão fundamentados em experiências vividas pelo conjunto da humanidade ao longo de sua história cultural e que se repetem constantemente. Deste modo, para Jung: "0 arquétipo é uma espécie de aptidão para reproduzir constantemente as mesmas ideias míticas; se não, as mesmas, pelo menos parecidas. Parece, portanto, que aquilo que se impregna no inconsciente é exclusivamente a ideia da fantasia subjetiva provocada pelo processo físico. Logo, é possivel

\section{Celso Candido Azambuja*}

0 iluminismo de todos os tempos sonhou com a vitória do conhecimento e da arte sobre as forças interiores e exteriores adversas ao Homem. Ésquilo não analisa esta crença em Prometeu. Celebra apenas o herói pelos benefícios que trouxe à humanidade, ajudando-a no seu esforço para passar da noite ao dia por meio do progresso e da civilização.

Werner Jaeger

\section{Introdução}

mito grego de Prometeu representa uma imagem primordial da condição humana. (1) Nele encontramos ricas conexões e intuições teóricas para a investigação das origens do pensamento ocidental. (2)

Prometeu é o deus-titã sacrificado por Zeus por ter ousado proteger os humanos, roubando dos deuses e dando a eles o fogo, símbolo de todas as artes e técnicas de que os seres humanos, então, eram desprovidos. Ele representa a imagem arquetípica da prospecção, da previsão e, portanto, da manipulação do tempo; ou seja, da inserção do homem em uma nova dimensão do tempo, projetiva e não mais cíclica, na qual estão contidos e limitados todos os seres da natureza. (3) 
interpretations of Werner Jaeger and Junito Brandão. In the poems of Hesiod, Prometheus is one Titan who stole fire from Zeus to give it to humanity. By this gesture, Prometheus and his protected are severely punished by Zeus. So immersed in a world of endless and unavoidable evils, men, honest, have a hope of a good life through working tirelessly. In the tragedy of Aeschylus, Prometheus is shown as the illuminator and protector of humanity. Multi-wise, he gave men the ability to think, for they were all without reason. All technical and human arts are due to Prometheus, the foresight. Here the myth reveals the background where wisdom springs from: suffering and pain. In the myth, it appears, essentially, the requirement of work and the presence of suffering as a condition of human existence defined and considered from the standpoint of the Enlightenment. Wisdom is the force that can make men overcome obstacles and adversities. Prometheus is thus a primordial image of the human condition whose wisdom is gained through work and pain.

KEYWORDS: Prometheus, Wisdom, Work, Pain

Prometeu traz o bem e a salvação para a humanidade, ao passo que os males vêm de seu irmão Epimeteu, aquele que pensa depois, o imprevidente. Este é o arquétipo que representa a imprevisão e a estultice do momento, a subordinação à natureza, ao dado e ao tempo cíclico que retorna sempre. (4)

No mito, tal como encontramos nas poesias de Hesíodo e na tragédia de Ésquilo, os bens humanos são dádivas de Prometeu, o previdente, o inventor e doador das técnicas aos homens néscios. Com a entrega do fogo, símbolo das técnicas e da inteligência, Prometeu transforma o percurso dos destinos humanos, tornando possível uma existência humana inteligente e projetiva.

\section{Prometeu de Hesíodo}

Nos poemas, Os trabalhos e os dias e Teogonia (séc. VIII-VII aC, prov.), Hesíodo apresenta Prometeu como aquele deus que roubou o fogo a Zeus para entregá-lo à humanidade néscia e sofredora. Este deus pretensioso, "Prometeu de curvo-tramar" que enfrenta Zeus, "Deus dos homens e dos Deuses", para o bem da humanidade é, na poesia de Hesíodo, o herói mitológico protetor da humanidade. Em razão de seu amor à humanidade, enganou Zeus que, por isso, o castiga cruelmente.

Segundo a Teogonia, Zeus castigou duramente Prometeu por este pretender beneficiar a humanidade em detrimento dos deuses. Mandou prendê-lo com correntes inquebrantáveis ao meio de uma coluna “...e sobre ele incitou uma águia de longas asas/ela comia o fígado imortal, ele crescia à noite/ todo igual o comera de dia a ave de longas asas..." (HESÍOD0, 2001, p. 135) Prometeu enganara Zeus em duas ocasiões. Primeiro, quando em Mecona, se “discerniam Deuses e homens mortais", Prometeu, ao dividir um grande boi, astutamente, reservou para os homens as carnes e para os deuses, as alvas gorduras e, depois, quando roubou o fogo a Zeus. (5)

Leiam-se os versos de Hesíodo (2001, p. 135-9) em que são apresentadas, na Teogonia, a cólera e o ressentimento de Zeus contra Prometeu e seus protegidos:

\section{...Zeus de impereciveis desígnios}

soube, não ignorou a astúcia; nas entranhas previu males que aos homens mortais deviam cumprir-se. Com as duas mãos ergueu a alava gordura,

raivou nas entranhas, o rancor veio ao seu ânimo, quando viu alvos ossos do boi sob dolosa arte. Por isso aos imortais sobre a terra grei humana Queima os alvos ossos em altares turiais.

E colérico disse-lhe Zeus agrega-nuvens:

"Filho de Jápeto, o mais hábil em seus desígnios, ó doce, ainda não esqueceste a dolosa arte!". Assim falou irado Zeus de imperecíveis desígnios...

Deste modo, Zeus negou aos homens o fogo. Mas uma vez mais Prometeu engana Zeus roubando- the o fogo e entregando-o aos homens. Furioso Zeus decide criar um mal para os mortais.

Vejam-se os versos de Hesíodo (1996, p. 25-7), em que são introduzidos, a partir da cólera de Zeus, os mitos de Prometeu e Pandora em Os trabalhos e os dias:

\section{Então encolerizado disse o agrega-nuvens Zeus:}

Filho de Jápeto, sobre todos hábil em tuas tramas, apraz-te furtar o fogo fraudando-me as entranhas; grande praga para ti e para os homens vindouros! supor que os arquétipos sejam as impressões gravadas pela repetição de reações subjetivas." ( $p$ 61/2) 0s arquétipos são imagens originárias que se constituem como "forças ou tendências" que levam "à repetição das mesmas experiências". Dessa maneira, um arquétipo "traz consigo uma 'influência' específica ou uma força que the confere um efeito numinoso e fascinante ou que impele à ação." Assim, é “a partir do tesouro das imagens primordiais" que se produzem as inovações e as novas formas (eidos) subjetivas e sociais. 0 arquétipo seria, pois, “.. uma espécie de força primordial que se apodera da psique e a impele a transpor os limites do humano, dando origem aos excessos, à presunção (inflação!) à compulsão, à ilusão ou à comoção, tanto no bem como no mal." (p. 61/2) É, a partir destas "imagens primordiais", que surgem e ressurgem os novos eidos do social, as ideias e os heróis, gênios ou santos.

2. Ao mesmo tempo, ele apresenta elementos originários fundamentais para a compreensão de nossa atualidade, definida em grande parte pela hegemonia da tecnociência.

3. Conforme a interpretação do mito de Galimberti (2006).

4. De acordo com BRANDÃO (1999, v. I, p. 166), a "etimologia mais provável" de Prometeu, "provém de... (pró), "antes de" e... ("mêthos), saber, ver", significa exatamente o que o latim denomina purens, de prouidens, o prudente, o 'pre-vidente', o que percebe de antemão. Filho do Titã Jápeto e da Oceânida Clímene, era irmão de Epimeteu, Atlas e Menécio." Ainda segundo BRANDÃ0 (1999, v. I, p. 168), “Epimeteu, de epí, sobre, depois, e ... (me-theús), ver, saber. Por oposição a Prometeu, que vê antes, Epimeteu vê depois. E viu!". Segundo Lafer (1996, p. 29), “Epimeteu é irmão e reverso de Prometeu; seu nome indica que ele tem a compreensão dos fatos só após terem eles acontecido, como podemos verificar no mito. Fala-se em "prometéia" e em "epimetéia", como formas de inteligência do fatos."

5. Conforme Brandão (1999, v.II p. 161), “com o sacrifício cruento em Mecone, (...) Prometeu, tendo abatido um boi e reservado astutamente para os deuses os ossos cobertos de gordura e para os homens as carnes, desencadeou 
Para esses em lugar do fogo eu darei um mal e todos se alegrarão no ânimo, mimando muito este mal.

Este mal será Pandora que, sendo dotada de a cólera de Zeus. Profundamente irritado com o logro do primeiro sacrifício que os mortais faziam aos deuses por meio de Prometeu, senhor do Olimpo privou aqueles do fogo e pôs termo ao estado paradisíaco, quando os homens viviam em perfeita harmonia com os imortais. Ora, com sua recusa em comer carne, decisão de não participar de sacrifícios cruentos e prática do vegetarianismo, os órficos visavam também, de algum modo, a purgar a falta ancestral recuperar a felicidade perdida." 6. Segundo Brandão

(1999, v.II, p. 168), “Pandora provém, em grego, de pan, todo, dôron, dom, presente, e significa "a detentora de todos os dons", um presente de todos os deuses. Do ponto de vista religioso Pandora é uma divindade da terra e da fecundidade."

encantos mil, no entanto, leva aos homens, através da curiosidade feminina, os "males sem fim". (6) Zeus, o agrega-nuvens de invencíveis desígnios, ordena a Hermes colocar neste belo corpo de mulher, "espírito de cão e dissimulada conduta". (HESÍODO, 1996, p. 27)

Foi Hermes quem deu a este mal o nome de Pandora, “...porque todos os que têm Olímpia morada deram-lhe um dom, um mal aos homens que comem pão". E foi ele quem levou a Epimeteu o presente. Irmão de Prometeu, Epimeteu, cujo nome significa "reflexão tardia", ou "aquele que conhece depois" em oposição a Prometeu, o previdente, aceitou o presente, abrindo, assim, o caminho para todos os males que sofrem os humanos sobre a terra.

De acordo com Hesíodo (1996, p. 23-9) Epimeteu não ouvira o conselho de Prometeu de jamais aceitar presente de Zeus, devendo devolvê-lo para evitar o mal aos mortais. Então os homens que viviam ao abrigo dos males, das doenças e dos trabalhos começaram a penar no mundo, a partir do momento em que “...a mulher, a grande tampa do jarro alçando/Dispersou-os e para os homens tramou tristes pesares." Desde então os homens sofrem, por todos os lugares males sem fim, "em silêncio, pois o tramante Zeus a voz lhes tirou".

Com os mitos de Prometeu e Pandora, Hesíodo procura uma explicação para o sem sentido do sofrimento e dos incontáveis males experimentados pelos humanos na terra.

Da mesma forma, o mito das Cinco raças conta o modo através do qual os homens que, originalmente viviam como deuses, acabam por degenerar ao estado lamentável que se encontram.

Assim, segundo Hesíodo (1996, p. 31-6), durante o período da Raça de Ouro, os homens viviam sem males, doenças, "morriam como tomados pelo sono". Tudo aí era abundante. Cobertos pela terra, tornaram-se, por Zeus, “...corajosos, ctônicos, curadores dos homens mortais." Já, na Raça de Prata, "bem inferior", os homens eram desmedidos, sem devotarem-se aos deuses, foram ao cabo, transfor- mados em "hipoctônicos, venturosos pelos mortais, segundos", apesar de honra os acompanhar. Durante a existência da Raça de Bronze, eram guerreiros invencíveis, que, entretanto, sucumbiram pelas próprias mãos até o "gélido Hades; anônimos", vivendo sem a luz do sol. Em seguida, Zeus fez ainda uma quarta "...mais justa e mais corajosa raça divina de homens heróis e são chamados semideuses, geração anterior à nossa na terra sem fim", a Raça dos Heróis. Por fim, gerou-se a Raça de Ferro, que corresponde à forma atual do humano. Aí, os homens “nunca durante o dia cessarão de labutar e penar e nem à noite de se destruir; e árduas angústias os deuses thes darão." Mas, continua, bens a esses males "estarão misturados". Mas, ímpios, invejosos, ciumentos, ingratos, desrespeitosos acabarão por ser destruídos por Zeus. Os imortais “...tristes pesares vão deixar aos homens mortais. Contra o mal força não haverá!".

Este lastimável estado no qual os homens na idade de ferro se encontram, pode ser transformado pelos homens honestos através do recurso ao trabalho. Assim, Hesíodo será o poeta que cantará os feitos do homem trabalhador, em uma nítida atmosfera comercial e pacífica, algo diferente daquela sugerida pelos poemas homéricos. Ele fará, pois, o elogio do trabalho como meio de superar ou minorar os males e sofrimentos humanos e como meio da justiça. Hesíodo (1996, p. 45-7) exorta seu irmão, Perses, com o qual se encontrava em atrito, a seguir o caminho de uma vida digna através do trabalho:

Mas tu, lembrando sempre do nosso conselho,

Trabalha, ó Perses, divina progênie, para que a fome Te deteste e te queira a bem coroada e veneranda

Deméter, enchendo-te de alimentos o celeiro;

Por trabalhos os homens são ricos em rebanhos $e$ recursos

e, trabalhando, muito mais caros serão aos imortais.

0 trabalho, desonra nenhuma, o ócio desonra é!

0 trabalho conduz à prosperidade e é próprio à condição do homem justo. A rapinagem não é boa coisa, é doadora de morte. Ao contrário, doar é coisa boa, "pois o homem que dá de bom grado, mesmo 
doando muito/alegra-se com o que tem e em seu ânimo se compraz". E, depois de aconselhar o irmão a ter cuidado com as mulheres, "de insinuadas ancas" que, não têm em mira, senão o "celeiro", conclui: "Se nas entranhas riqueza desejar teu ânimo, assim faze: trabalho sobre trabalho, trabalha." (HESÍOD0, 1996, p. 49-51)

Assim, é no trabalho que o homem pode encontrar a única esperança de uma vida boa, justa e pacificada.

\section{1}

Para Werner Jaeger, Hesíodo é o poeta do trabalho e da justiça, é aquele que instaurou o "mundo do espírito". Segundo Jaeger (1995, p. 85), a obra de Hesíodo revela uma cultura e uma sociedade muito diferentes daquela de Homero. Os “Erga, apresenta a mais viva descrição da vida campestre da metrópole grega no final do séc. VIII [aC]." Enquanto a obra de Homero acentuará sobretudo "que toda a educação tem o seu ponto de partida na formação de um tipo humano nobre, o qual nasce do cultivo das qualidades próprias dos senhores e dos heróis".

De acordo com Jaeger (1995, p. 85), em Hesíodo, afirma-se o "valor do trabalho" como “segunda fonte da cultura". Isto é confirmado pela tradução que a posteridade deu ao título da obra: Os trabalhos e os dias. É preciso, pois, observar que "a vida despreocupada da classe senhorial em Homero, não deve induzir-nos em erro: a Grécia exige dos seus habitantes uma vida de trabalho".

A forma e o conteúdo da obra, seja no mito de Prometeu no qual “...Hesíodo encontra a solução para o problema do cansaço e dos sofrimentos da vida humana", seja no mito das Cinco idades, o qual deveria explicar a razão da "...enorme distância entre a própria existência e o mundo resplandecente de Homero, e reflete a eterna nostalgia do Homem por melhores tempos", seja ainda no "...mito de Pandora, que é alheio ao pensamento cavalheiresco e exprime a concepção triste e prosaica da mulher como fonte de todos os males", revelam, segundo Jaeger, a "herança popular" de Hesíodo em total contraste "à cultura da nobreza" homérica. (JAEGER , 1995, p. 89-90)
0 trabalho e os sofrimentos devem ter aparecido algum dia no mundo. Não podem ter feito parte, desde a origem, da ordem divina e perfeita das coisas. Hesíodo assinala-lhes como causa a sinistra ação de Prometeu, o roubo do fogo divino, que encara do ponto de vista moral. Como castigo, Zeus criou a primeira mulher, a astuta Pandora, mãe de todo o gênero humano. Da caixa de Pandora, saíram os demônios da doença, da velhice, e outros males mil que hoje povoam a Terra e o mar. (JAEGER, 1995, p. 95)

Hesíodo seria o poeta da diké, o "profeta do direito". Segundo Jaeger, Hesíodo deixa claro que a rapina e a luta traz infelicidade, incerteza e que portanto é preciso reconhecer o "valor do trabalho". "0 trabalho é celebrado como o único caminho, ainda que difícil, para alcançar a arete. 0 conceito abarca simultaneamente a habilidade pessoal e 0 que dela deriva - bem-estar, êxito, consideração". A arete em questão não é mais a aristocrática guerreira, como em Homero, mas a “...do homem trabalhador, que tem a sua expressão numa posse de bens moderada". (JAEGER , 1995, p. 100) Assim, o que importa é uma virtude que será alcançada com o suor do próprio rosto.

Em Hesíodo, não importam mais as atividades competitivas ligadas à moral aristocrática, mas aqueles associadas à "calada e tenaz rivalidade no trabalho". (JAEGER , 1995, p. 100) Ganhar o pão com o suor do próprio rosto não uma maldição, mas uma benção necessária. Pois é através dele que o homem conquista a virtude, a arete. Assim, segundo Jaeger "ressalta, com perfeita nitidez, que Hesíodo quer com plena consciência colocar ao lado do adestramento dos nobres, tal como se espelha na epopéia homérica, uma educação popular, uma doutrina da arte do homem simples". (JAEGER , 1995, p. 100) Esta doutrina encontra na justiça e no trabalho as bases fundamentais nas quais ela e sustenta.

É, pois, com Hesíodo que uma nova classe popular até então excluída da cultura ganha sua autoconsciência e independência. (JAEGER, 1995) Em suma, é com o poeta Hesíodo que segundo Jaeger “...começa o domínio e o governo do espírito, que põe o seu selo no mundo grego. É o 'espírito', no sentido original, o autêntico spiritus, o sopro dos 
deuses, que ele próprio descreve como verdadeira experiência religiosa...". (JAEGER , 1995, p. 105)

Assim, justiça e virtude estarão associadas à capacidade de trabalho do homem. Com isto passa ao centro das preocupações não mais o espírito de guerra e a rapina, mas o cálculo de um benefício talvez menor e seguramente mais sofrido, mas certamente mais seguro e justo, através do trabalho, cuja atividade é um constante desafio. Será preciso, pois, aceitar o sofrimento do trabalho como condição de uma vida justa e pacificada.

\section{2}

A análise de Junito de Souza Brandão sustenta tese semelhante à de Jaeger. Segundo Brandão (1999, v.I, p. 163/4), duas leis fundamentais na Teogonia “... estão intimamente ligadas: a necessidade do trabatho e o dever de ser justo. Trabalho e Justiça jamais poderão separar-se, porque a carência do primeiro gera a violência, isto é, a injustiça”. A “...lei do trabalho é fundamentada numa razão metafísica, quer dizer, num mito: o mito de Pandora", que se inicia já com o castigo de Prometeu. Nos Erga, Hesíodo faz um elogio do trabalho e da justiça. 0 trabalho aparece como “...um preceito imposto pela vingança de Zeus. 0 mito de Prometeu e Pandora explica a origem dessa lei, assim como todas as desgraças que atormentam o homem...", enquanto que, com o mito das Cinco Idades, se revela a "necessidade da justiça”. Somente "...a dedicação ao trabalho e à justiça assegura a prosperidade nesta vida e a recompensa na outra. Ao revés, os que se deixam dominar pela hýbris, pela 'démesure', pelo descomedimento, serão implacavelmente castigados nesta e no além" (BRANDÃ0, 1999, v.I, p. 164).

De acordo com Brandão (1999, v.I, p. 165), em “...Hesíodo, o ánthropos, o homo, isto é, o húmus, o barro, a argila, o 'descendente' de Epimeteu e Pandora", é aquele "que ganha a vida duramente com o suor de seu rosto", enquanto, em "...Homero, o herói se mede por sua arete, excelência, time e honra pessoal; em Hesíodo, a arete e a time se traduzem pelo trabalho e pela sede de justiça".

Os mitos de Prometeu e Pandora “...explicam a origem do 'desígnio do pai dos deuses e dos homens a que ninguém escapa' e a punição dos mortais" (BRANDÃ0, 1999, v.I, p. 166). Prometeu, "filho de Jápeto, bem antes da vitória final de Zeus, já era um benfeitor da humanidade. Essa filantropia, aliás, the custou muito caro."

Foi pelo seu amor pelos homens que Prometeu acabou por enganar seu primo Zeus que

...vendo-se enganado, 'cólera encheu sua alma, enquanto o ódio lhe subia ao coração'. 0 terrivel castigo de Zeus não se fez esperar: privou o homem do fogo, quer dizer, simbolicamente do nûs, da inteligência, tornando a humanidade anóetos, isto é, imbecilizou-a. (BRANDÃO, 1999, v.I p. 166)

Entretanto, uma vez mais o heróico Prometeu ousou enfrentar Zeus, “...roubou uma centelha do fogo celeste, privilégio de Zeus, ocultou-a na haste de uma férula e a trouxe à terra, 'reanimando' os homens. 0 Olímpico resolveu punir exemplarmente os homens e a seu benfeitor". (BRANDÃ0, 1999, v.I p. 167) Zeus, então, imaginou para os humanos, tristes pesares, através de uma mulher, a "irresistível Pandora" e contra Prometeu sofrimentos sem igual.

Consoante a Teogonia (521-534), Prometeu foi acorrentado com grilhões inextricáveis no meio de uma coluna. Uma águia enviada por Zeus lhe devorava durante o dia o figado, que voltava a crescer à noite. Heracles, no entanto, matou a águia e libertou Prometeu, com a anuência do próprio Zeus, que desejava se ampliasse por toda a terra a glória de seu filho, e a despeito de seu ódio, Zeus renunciou ao ressentimento contra Prometeu... (BRANDÃO, 1999, v.I, p. 167)

Quanto ao "belo mal", foi, de acordo com a intepretação de Brandão (1999, v.I, p. 168), Hermes que the encheu “...o coração de artimanhas, impudência, astúcia, ardis, fingimento e cinismo. (...) Por fim, o mensageiro dos deuses concedeu- the o dom da palavra e chamou-a Pandora, porque são todos os habitantes do Olimpo que, com este presente, 'presenteiam' os homens com a desgraça!". Foi, pois, Pandora que, por curiosidade, levou o mal aos homens. Até então, a humanidade vivia como raça divina, sem doenças, fadigas, maldades, “mas, 
quando Pandora, por curiosidade feminina, abriu a jarra de larga tampa, que trouxera do Olimpo, como presente de núpcias a Epimeteu, dela evolaram todas as calamidades e desgraças que até hoje atormentam os homens. Só a esperança permaneceu presa junto às bordas da jarra..." (BRANDÃ0, 1999, v.I, p. 168).

Por sua vez, o mito das Cinco idades, para Brandão (1999, v.I, p. 169), é introduzido por Hesíodo como forma de explicar a degeneração e corrupção humana. Entretanto, este mito não revela “...apenas a decadência do homem, mercê do 'crime' de Prometeu e do envio de Pandora, mas, acima de tudo, a necessidade do trabalho e o dever de ser justo" (BRANDÃO, 1999, v.I, p. 170).

Segundo Brandão (1999, v.I, p. 172), “Hesíodo apresentou o mitologema das Cinco Idades dentro de um esquema trifuncional". Nas idades de ouro e prata, “há nítido predomínio da Díke (Justiça)"; em segundo plano “...(bronze e heróis) reina a Hýbris (a Violência); e o “...terceiro (ferro) está vinculado a um mundo ambíguo, definido pela coexistência dos contrários: (...) Díke e Hýbris, Justiça e Violência, uma ao lado da outra, oferecem ao homem duas opções igualmente possiveis entre as quais compete a ele escolher".

Sinteticamente, pode-se dizer que, no mito das Cinco idades, na Idade de Ouro, não existe guerra nem trabalho. Reina Díke, a Justiça. Na Idade de Prata, não há guerra nem trabalho também, mas há o predomínio da Hýbris. Na Idade de Bronze, não há trabalho, mas faz-se a Guerra. Durante a Idade dos Heróis, encontram-se os heróis da Hýbris e os heróis da Díke (BRANDÃ0, 1999, v.I, p. 172-6). E, por fim, na Idade de Ferro, existe trabalho e sofrimentos sem fim.

A necessidade de sofrer e batalhar na terra para obter o alimento é igualmente para o homem a necessidade de gerar através da mulher, nascer e morrer, suportar diariamente a angústia e a esperança de um amanhã incerto. É que a idade de ferro tem uma existência ambivalente e ambigua, em que o bem e o mal não estão somente amalgamados, mas ainda são solidários e indissolúveis. (BRANDÃO, 1999, v. I, p. 177)

Por isto, apesar de todos os males vindos com
Pandora, "o homem, rico de misérias nesta vida, não obstante se agarra" a ela, “o mal amável". De acordo com a perspectiva de Brandão (1999, v. I, p. 177) “As desgraças, porém, despejaram-se pelo mundo; resta, todavia, a Esperança, pois, afinal, a vida não é apenas infortúnio: compete ao homem escolher entre o bem e o mal."

Ainda segundo Brandão (1999, v. I, p. 178), o mito de Pandora representa o mundo ambíguo no qual vivemos. Simbolizando a "mulher" e a "terra", o mito representa "a função da fecundidade, tal qual se manifesta na idade de ferro na produção de alimentos e na reprodução da vida". Distante daquele tempo de outro em que a abundância era espontânea “...de agora em diante, é o homem quem deposita a sua semente (spérma) no seio da mulher, como o agricultor a introduz penosamente nas entranhas da terra.

Brandão (1999, v. I, p. 179), deste modo, elabora uma síntese das idades. Nas idades paradisíacas primeiras que Hesíodo chama de outro e prata, “...o destino final do homem é tornar-se respectivamente daímon epikhthónios ou hypokhthónios, isto é, a psiqué, sobre ou sob a terra, passa a funcionar como espírito intermediário entre os deuses e os homens. Trata-se, por conseguinte, de uma promoção."

Quanto às idades de bronze e dos heróis sucede o contrário.

....após a morte, são lançados no Hades, onde, semelhantes à fumaça, se convertem em mortos anônimos, sem direito a honras ou a culto, por parte dos vivos. Hesiodo não fala em penas, em tormentos, mas pelo fato de se transformarem em mortos anônimos, sem nenhum direito a culto, fica subentendido que 'essas sombras' nada mais são que uma fumaça esquiva, o que constitui, para o pensamento grego, no maior dos castigos, o deixar de ser. Os heróis, porém, amantes da Díke, terão como recompensa eterna a Ilha dos Bem-Aventurados.

No que diz respeito à idade de ferro, segundo Brandão (1999, v. I, p. 179), o poeta nada diz acerca de algum além. Ao contrário, “tem-se a impressão, salvo engano, de que o paraíso e o inferno da idade de ferro, que será, além do mais, prolongada por criaturas ainda piores, estão aqui mesmo". Trata-se, 
portanto de escolher entre dedicar-se "ao trabalho, à justiça e ao respeito aos deuses" ou deixar-se levar pela Hýbris, o descomedimento, a injustiça e a ociosidade. Os primeiros "terão seus celeiros cheios e uma vida farta e tranquila", os outros "serão escravos da fome e da miséria".

Assim, em Hesíodo, seja no mito das cinco idades, seja principalmente no mito de Prometeu, a dedicação ao trabalho, com todos os seus pesares e dores inevitáveis, é o horizonte que se abre ao homem identificado com uma vida pacífica, comedida e justa. 0 homem será senhor do seu destino somente na medida em que se lança com tenacidade ao trabalho, dia após dia, sem descanso. Caso contrário, ocioso e incontinente, se tornará escravo da sorte e da injustiça, do acaso e da violência.

\section{Prometeu de Ésquilo}

Outra versão do mito de Prometeu é apresentada, ainda na antiguidade grega, pelo poeta trágico Ésquilo (1984a), em sua obra Prometeu acorrentado, na qual se revelam principalmente os elementos e virtudes intelectuais e ao caráter trágico do herói. Prometeu sabe que foi seu humanismo, seu desejo de ajudar aos "homens desgraçados" a causa de sua desdita. Prometeu é, pois, o deus protetor dos homens. "Previdente", "astuto", “multissábio", foi ele quem thes deu razão e pensamento, pois faziam tudo "sem razão". As artes e as técnicas, os números e as palavras também são dádivas de Prometeu. Enfim, todas as technes humanas são devidas a Prometeu: os remédios, as curas, a adivinhação, o conhecimento dos sonhos. Prometeu é também profeta e conselheiro. Por fim, em um fragmento de Ésquilo (1984b, p. 219) de obra intitulada Prometeu portador do fogo, o coro canta Prometeu como aquele que dá a vida e os dons aos homens.

\section{1}

Para Jaeger (1995, p. 309), o Prometeu acorrentado, de Ésquilo, seria a "tragédia do Gênio", a tragédia do espírito. Enquanto na maioria de suas obras, a tragédia acontece desde fora, porque vem de fora, em Prometeu acorrentado, ela vem de dentro. Os sofrimentos do deus titânico foram originados por uma ação desejada e deliberada de modo plenamente consciente e autônomo. Entretanto, essa não diz respeito a uma tragédia de tipo pessoal. Trata-se da "tragédia da criação espiritual". Prometeu, ele mesmo, é o "fruto espontâneo da alma de poeta de Ésquilo".

Prometeu torturado, de acordo com Jaeger (1995, p. 209) “...encarna para Ésquilo o destino da humanidade. (...) Todos os séculos viram nele a imagem da Humanidade".

Jaeger, desta maneira, formula a ideia de que a fé fundamental de Ésquilo, seria precisamente a concepção de que somente pela dor e pelo sofrimento, o ser humano pode chegar ao conhecimento. De acordo com Jaeger (1995, p. 313), ao contrário de Hesíodo para quem Prometeu não passava de um traidor que roubou o fogo de Zeus, sendo por isto castigado, Ésquilo cuja força de imaginação nós nunca saberemos "honrar e admirar suficientemente",

...descobriu nesta façanha o germe de um símbolo humano imortal: Prometeu é o que traz a luz à humanidade sofredora. 0 fogo, essa força divina, torna-se o símbolo sensivel da cultura. Prometeu é o espírito criador da cultura, que penetra e conhece o mundo, que o põe a serviço da sua vontade por meio da organização das forças dele de acordo com os seus fins pessoais, que the descobre os tesouros e assenta em bases seguras a vida débil e oscilante do Homem. (JAEGER, 1995, p. 313)

Segundo Jaeger (1995, p. 310), ainda, “...a concepção fundamental do roubo do fogo encerra uma ideia filosófica de tão grande profundidade e grandiosidade humana, que o espírito do Homem jamais a poderia esgotar". Prometeu representa assim a "heroica audácia espiritual" do homem. Diz Jaeger (1995, p. 311):

0 iluminismo de todos os tempos sonhou com a vitória do conhecimento e da arte sobre as forças interiores e exteriores adversas ao Homem. Ésquilo não analisa esta crença em Prometeu. Celebra apenas o herói pelos beneficios que trouxe à humanidade, ajudando-a no seu esforço para passar da noite ao dia por meio do 
progresso e da civilização.

De acordo com Jaeger (1995, p. 312) Prometeu representa o poder do "espírito criador" do homem. Prometeu reconhece o valor superior do espírito como princípio governante do mundo, por isso separa-se dos titãs. Ele percebeu “...que a sua causa era desesperada, por só reconhecerem a força bruta, quando é apenas o engenho espiritual que governa o mundo". Entretanto, Prometeu continua sendo “...um titã, pelo seu desmedido amor, que pretende erguer violentamente a humanidade sofredora acima dos limites que the impôs o soberano do mundo, e pelo orgulhoso ímpeto da sua força criadora".

Assim, este pathos trágico da auto-superação do homem "se eleva do sentimento à reflexão, do afeto trágico ao conhecimento trágico. Chega, com isso, ao mais alto ponto que a tragédia pretende atingir." (JAEGER, 1995, p. 312)

Deste modo, consuma-se a fé fundamental de Ésquilo na bênção da dor. É no caminho da dor que se vence o caos. Nesse caminho, encontra-se “...o fundamento originário da religião trágica de Ésquilo. Todas as suas obras se fundam nesta grande unidade espiritual" (JAEGER, 1995, p. 313).

A fé na ideia de que o sofrimento é uma benção, segundo Jaeger $(1995,313)$ revela a força gigantesca de "uma vontade reformadora cheia de profundidade e de ardor".

Ésquilo, então, pode encontrar algum repouso e liberdade de espírito. A vitória de final Zeus sobre os Titãs é celebrada pelo poeta, pois trata-se simbolicamente da vitória do espírito sobre a violência, da cultura sobre o caos. E foi Zeus “cuja essência só pode ser pressentida nos efeitos dolorosos da sua ação" quem "rasgou aos mortais o caminho dos conhecimentos, com esta lei: pela dor à sabedoria".

Só neste conhecimento o coração do poeta trágico acha repouso e se liberta "do peso da dúvida que o atormenta". Serve-se, para tanto, do mito, que se transforma em puro símbolo, ao celebrar o triunfo de Zeus sobre o mundo originário dos titãs e da sua força provocadora da hybris. Apesar de todas as violações, sempre renovadas, a ordem vence o caos. Tal é o sentido da dor, ainda quando não o compreendemos (JAEGER,
1995, p. 314).

Finalmente Jaeger (JAEGER, 1995, p. 314) conclui sua interpretação do Prometeu de Ésquilo com palavras que expressam, com magnificência e gratidão, a importância e a grandeza da obra:

Eis, no Prometeu, o sentido da 'harmonia de Zeus', que os desejos e pensamentos humanos nunca poderão ultrapassar, e à qual, em último recurso, também a titânica criação da cultura humana terá de submeter-se.

Deste modo, de acordo com Jaeger (1995, p. 314) “o homem trágico, que criou a arte da tragédia" situado no interior desta harmonia celestial “... expande a sua oculta harmonia com o ser e se ergue pela sua capacidade de sofrimento e pela sua força vital, a um grau superior de humanidade".

Assim, o caminho do sofrimento e a fé na benção da dor determinam as possiblidades da sabedoria humana e, portanto, as chances que uma existência incerta tem para vencer e superar o caos e a violência através da sua heroica audácia espiritual.

\section{Conclusão}

0 mito de Prometeu revela a essência e o sentido do sofrimento e da sabedoria humana. 0 trabalho e suas penas são condições necessárias de uma humanidade sofredora que, em meio a tantos males, busca o ideal de uma vida pacificada, boa e justa. Ao mesmo tempo, o mito revela o nascimento do espírito como a tragédia propriamente humana. 0 sofrimento é uma benção que conduz a humanidade à sabedoria, sem a qual o homem jamais teria conseguido ultrapassar a si mesmo e constituir o mundo da cultura. (7)

\section{Referências}

BRANDÃO, J. S. Mitologia grega. Rio de Janeiro: Vozes, 1999. 3v.

ÉSQUILO. Prometeo encadenado. Madrid: Hernando, 1984a.

ÉSQUILO. Fragmentos. Madrid: Hernando, 1984b.

GALIMBERTI, U. Psiche e Techne. 0 homem na idade da técnica. São Paulo: Paulus, 2006.

HESÍODO. Teogonia, a origem dos Deuses. São Paulo:
7. Espantamo-nos que a cultura humana tenha sua origem no mito do roubo de fogo e, portanto, na técnica? Mas não deveria espantar-nos ainda mais o fato de que em nossa atualidade tenhamos colocado em dois campos distintos e muitas vezes antagônicos techne e a paidéia? Que tenhamos perado uma fratura no seio do espírito humano através da oposição entre técnica e cultura? Assim, por mais improvável, paradoxal e contraditório que possa parecer, este problema crucial de nossa época transformase também em um caminho essencial para pensar a condição e os destinos humanos. 
Iluminuras, 2001.

HESÍODO. Os trabalhos e os dias. São Paulo: Iluminuras, 1996.

JAEGER, W. Paidéia. São Paulo: Martins Fontes, 1995.

JUNG, C. G. Psicologia do inconsciente. Rio de Janeiro: Vozes, 1995.

LAFER, M. C. M. Introdução, tradução e comentários. In: HESÍODO. Os trabalhos e os dias. São Paulo: Iluminuras, 1996.

Recebido em janeiro de 2012, aprovado em setembro de 2012. 